\title{
IMPROVEMENTS IN A FAST POTENTIOMETRIC SEAWATER ALKALINITY DETERMINATION
}

\section{DETERMINACIÓN POTENCIOMÉTRICA RÁPIDA DE LA ALKALINIDAD EN AGUA DE MAR: PERFECCIONAMIENTO DEL MÉTODO}

\author{
Fiz F. Pérez* \\ Aida F. Ríos, \\ Trinidad Rellán \\ Marta Álvarez \\ Instituto de Investigacions Marinas (CSIC) \\ Eduardo Cabello 6 \\ 36208 Vigo, España \\ *E-mail: fizfperez@iim.csic.es
}

Recibido en febrero de 1999; aceptado en abril de 2000

\begin{abstract}
In the present paper, we introduce some methodological improvements in a potentiometric technique for determining seawater alkalinity. This fast method (about two minutes per sample) uses open flasks and an ordinary titration system without thermostatic bath. A new potassium hydrogen phthalate-borax 4.4 buffer is proposed to calibrate the electrode near the end point of the titration. The $\mathrm{pH}$ values of this new buffer at different $\mathrm{pH}$-scales and temperatures were determined using spectrophotometry. The combined use of this easy and improved two end-point method for alkalinity determination and certified reference material enables the alkalinity to be determined with an accuracy lower than $1 \mu \mathrm{molkg}^{-1}$ $(0.05 \%)$.
\end{abstract}

Key words: seawater, alkalinity, fast method.

\section{RESUMEN}

En este artículo se mejora la metodología de una técnica potenciométrica para determinar la alcalinidad en agua de mar. Este método es simple y rápido (unos dos minutos por análisis); utiliza matraces abiertos y un sistema de valoración ordinario sin baño termostático. La mejora consiste en el uso de una disolución tampón de ftalato potásico-bórax de $\mathrm{pH} 4.4$ para calibrar el electrodo cerca del punto final de la valoración, con el añadido de que los valores de $\mathrm{pH}$ de esta disolución a distintas temperaturas se han obtenido mediante espectrofotometría. La utilización combinada de esta fácil valoración a doble punto final y de material certificado de referencia de $\mathrm{CO}_{2}$ nos permite determinar la alcalinidad con una exactitud menor que $1 \mu \mathrm{molkg}^{-1}(0.05 \%)$.

Palabras clave: agua de mar, alcalinidad, método rápido. 
Ciencias Marinas, Vol. 26, No. 3, 2000

\section{INTRODUCTION}

The four master parameters that define the seawater carbon dioxide system are total alkalinity $\left(\mathrm{A}_{\mathrm{T}}\right)$, total inorganic carbon $\left(\mathrm{C}_{\mathrm{T}}\right)$, hydrogen ion concentration expressed as $\mathrm{pH}$ and partial pressure of $\mathrm{CO}_{2}\left(\mathrm{pCO}_{2}\right)$. This system can be characterized by measuring two of the four parameters, using suitable equilibrium equations and constants (Skirrow, 1975). Although $\mathrm{C}_{\mathrm{T}}$ and $\mathrm{pCO}_{2}$ are the most sensitive to all marine processes involved in the global carbon cycle and particularly to anthropogenic effects, until this decade the most frequently measured were $\mathrm{pH}$ and $\mathrm{A}_{\mathrm{T}}$. This fact can be attributed to the reliability and convenience of at-sea methods for measuring these variables, especially the potentiometric ones. Nevertheless, potentiometric $\mathrm{pH}$ and $\mathrm{A}_{\mathrm{I}}$ determinations are quite susceptible to systematic errors. In this sense, calculated $\mathrm{C}_{\mathrm{T}}$ and $\mathrm{pCO}_{2}$ are a little more imprecise than direct coulometric determinations for $\mathrm{C}_{\mathrm{T}}$ (Johnson et al., 1993) or direct measurements of $\mathrm{pCO}_{2}$ with an IRGA gas equilibrator system (Wanninkhof and Thoning, 1993; Körzinger et al., 1996).

Fossil fuel burning causes atmospheric $\mathrm{CO}_{2}$ to increase, leading to an increment of about $1 \mu \mathrm{molkg} \mathrm{kg}^{-1}$ and $1.5 \mu \mathrm{atm}$ per year in oceanic $\mathrm{C}_{\mathrm{T}}$ and $\mathrm{pCO}_{2}$, respectively. Detecting and mapping these slight temporal changes in the ocean needs methodologies that are not only accurate and precise but also handy and fast at-sea. Nowadays, $\mathrm{pH}$ can be easily measured with an accuracy lower than $0.001 \mathrm{pH}$ units using spectrophotometric procedures (Clayton and Byrne, 1993), reducing the difference between measured and calculated $\mathrm{pCO}_{2}$ below $1 \mu$ atm. On the other hand,

\section{INTRODUCCIÓN}

Los cuatro principales parámetros que definen el sistema del carbónico en agua de mar son la alcalinidad total $\left(\mathrm{A}_{\mathrm{T}}\right)$, el carbono inorgánico total $\left(\mathrm{C}_{\mathrm{T}}\right)$, la concentración total de hidrogeniones expresada en términos de $\mathrm{pH}$ y la presión parcial de $\mathrm{CO}_{2}\left(\mathrm{pCO}_{2}\right)$. Este sistema se puede caracterizar midiendo únicamente dos de los cuatro, usando las correspondientes ecuaciones y constantes de los equilibrios termodinámicos del $\mathrm{CO}_{2}$ en agua de mar (Skirrow, 1975). Aunque el $\mathrm{C}_{\mathrm{T}}$ y la $\mathrm{pCO}_{2}$ son los parámetros más sensibles a los procesos marinos involucrados en el ciclo global del carbono y particularmente a los efectos antropogénicos, hasta esta década los más frecuentemente medidos fueron el $\mathrm{pH}$ y la $\mathrm{A}_{\mathrm{T}}$. La razón de esto son la reproducibilidad y comodidad de los métodos para medir estas variables en condiciones de barco, con especial referencia a los métodos potenciométricos. En contrapartida, este tipo de metodologías es muy susceptible a errores sistemáticos. Así, el $\mathrm{G}_{\mathrm{T}}$ y la $\mathrm{pCO}_{2}$ calculados en función del $\mathrm{pH}$ y la $\mathrm{A}_{\mathrm{T}}$ son algo más imprecisos que la determinación mediante coulometría del $\mathrm{C}_{\mathrm{T}}$ (Johnson et al., 1993) o la medida directa de $\mathrm{pCO}_{2}$ con un sistema equilibrador de gases IRGA (Wanninkhof y Thoning, 1993; Körzinger et al., 1996).

La quema de combustibles fósiles provoca un aumento del $\mathrm{CO}_{2}$ atmosférico y esto a su vezun aumento de alrededor de $1 \mu \mathrm{molkg}^{-1} \mathrm{y}$ $1.5 \mu$ atm por año en el $\mathrm{C}_{\mathrm{T}} \mathrm{y} \mathrm{pCO}_{2}$ oceánicos, respectivamente. Para la detección y representación de tan ligeros cambios en el océano se necesitan métodos exactos y precisos pero también manejables y rápidos en condiciones de barco. Actualmente, el pH se puede medir con una precisión menor que 0.001 unidades de $\mathrm{pH}$ usando procedimientos espectrofotométricos (Clayton y Byrne, 1993), así se reduciría la diferencia entre la $\mathrm{pCO}_{2}$ calculada y medida 
the combination of this procedure with the alkalinity potentiometric titration provides a handy and friendly alternative procedure to attain a similar accuracy between the estimated and measured $\mathrm{C}_{\mathrm{T}}$ and $\mathrm{pCO}_{2}$. Currently, the precision and reliability of alternative methods can be checked by means of analyzing certified reference material (CRM, A. Dickson, Scripps Institution of Oceanography, La Jolla, California).

The classical potentiometric methods to determine alkalinity are based on computerized systems that follow the titration curve and determine the end point (Dickson, 1981; Johansson and Wedborg, 1982; Millero et al., 1993a). These methods take about 30 minutes for each sample and the reproducibility is \pm 2 to $\pm 6 \mu \mathrm{molkg}{ }^{-1}$, determined from CRM analysis (Millero et al., 1993b). In addition, after a quick acidification with $\mathrm{HCl}, \mathrm{pH}$ is measured to evaluate its excess (Culberson et al., 1970; Breland and Byrne, 1993) until one or two end points are reached. Based on this method, Pérez and Fraga (1987a) showed the almost negligible loss of $\mathrm{C}_{\mathrm{T}}$ during the $\mathrm{A}_{\mathrm{T}}$ titration, and proposed a fast (about three minutes per sample) and precise potentiometric method for alkalinity determination in seawater using open flasks. In this paper, we improve the latter method and its accuracy by means of calibrating the electrode nearer the end point using a new phthalate-borax 4.4 buffer solution and by the simplification of the preparation and standardization of the $\mathrm{HCl}$ solution.

\section{MATERIAL AND METHODS}

Alkalinity was measured following Pérez and Fraga (1987a), using an automatic potentiometric titrator (type DMS Titrino 716, por debajo de $1 \mu \mathrm{atm}$. Por otro lado, combinado este procedimiento con la valoración potenciométrica de la alcalinidad se obtiene un método alternativo fácil y manejable, con precisiones similares a las obtenidas en la determinación directa de $\mathrm{C}_{\mathrm{T}}$ y $\mathrm{pCO}_{2}$. Actualmente, la precisión y reproducibilidad de estos métodos alternativos se puede comprobar analizando material de referencia certificado de $\mathrm{CO}_{2}$ (CRM, A. Dickson, Scripps Institution of Oceanography, La Jolla, California).

Los clásicos métodos potenciométricos para la determinación de la alcalinidad se basan en sistemas computarizados que siguen la curva de valoración y determinan el punto final (Dickson, 1981; Johansson y Wedborg, 1982; Millero et al., 1993a). Estos métodos precisan unos 30 minutos por cada muestra y su reproducibilidad varía de \pm 2 a $\pm 6 \mu$ molkg ${ }^{-1}$, determinada a partir del análisis de CRM (Millero et al., 1993b). Alternativamente, otras técnicas se basan en una rápida acidificación con $\mathrm{HCl}$, midiéndose el pH para evaluar el exceso de ácido (Culberson et al., 1970; Breland y Byrne, 1993) cuando se alcanza el punto final de la valoración $(\mathrm{pH} \cong 3$ ). Basados en esta técnica, Pérez y Fraga (1987a) propusieron una valoración potenciométrica a $\mathrm{pH}$ final de 4.4 para determinar la $\mathrm{A}_{T}$ de manera rápida (unos tres minutos por muestra) y precisa, durante la cual no existe prácticamente pérdida de $\mathrm{C}_{\mathrm{T}}$ aunque se use un matraz abierto. En este artículo, se mejora la exactitud y metodología de esta propuesta gracias al calibrado del electrodo más cerca del punto final de la valoración usando una disolución tampón 4.4 de ftalato-bórax y a la simplificación de la preparación y estandarización de la disolución de $\mathrm{HCl}$.

\section{MATERIAL Y MÉTODOS}

La alcalinidad se determinó según Pérez y Fraga (1987a), usando un valorador potenciométrico (tipo DMS Titrino 716 Metrohm), un 
Ciencias Marinas, Vol. 26, No. 3, 2000

Metrohm), a Metrohm 0233.100 combined reference glass electrode filled with $3 \mathrm{M} \mathrm{KCl}$. Potentiometric titration was carried out with $\mathrm{HCl}$ (0.1 M, see below) to two final $\mathrm{pHs}$ of 4.44 and 4.40 in order to get a better reproducibility and stable readings. The instrument was calibrated using a buffer $(\mathrm{pH} 4.395$ at $25^{\circ} \mathrm{C}$ ) made from potassium phthalate and sodium tetraborate (borax) in $\mathrm{CO}_{2}$ free seawater (see below). A gravimetrically calibrated Knudsen pipette (195 mL) was used to transfer the samples into a conical Erlenmeyer flask ( $206 \mathrm{~mL}$ of total volume). These types of flasks present in their upper part an air-solution interface area of less than $3 \mathrm{~cm}^{2}$. Thus, the loss of $\mathrm{CO}_{2}$ is negligible, allowing to resolve alkalinity from the initial and final $\mathrm{pH}$ of the sample (Pérez and Fraga, 1987a). All measurements were made under laboratory conditions and stable temperature (measured with a Pt-100 temperature probe).

Neglecting the micronutrient species, the alkalinity is given by electrodo combinado de referencia y vidrio Metrohm 0233.100 rellenado con 3M KCl. La valoración se llevó a cabo utilizando $\mathrm{HCl}$ ( $0.1 \mathrm{M}$, ver más abajo) hasta dos puntos finales de $\mathrm{pH} 4.44$ y 4.40; así se aumenta la fiabilidad de las medidas ya que se obtienen lecturas estables. El instrumento se calibró usando un tampón ( $\mathrm{pH} 4.395$ a $25^{\circ} \mathrm{C}$ ) de ftalato potásico y tetraborato de sodio (bórax) en agua de mar sin $\mathrm{CO}_{2}$ (ver más abajo). Se utiliza una pipeta Knudsen $(195 \mathrm{~mL})$ para traspasar la muestra a un matraz Erlenmeyer cónico (206 mL de volumen total). Este tipo de matraces presenta en su parte superior una interfaz aire-disolución con un área menor que $3 \mathrm{~cm}^{2}$. Así, la pérdida de $\mathrm{CO}_{2}$ es prácticamente despreciable, permitiendo calcular la alcalinidad a partir de los $\mathrm{pH}$ inicial y final de la muestra (Pérez y Fraga, 1987a). Todas las medidas se realizaron en condiciones de laboratorio a temperatura estable (medida con una sonda de temperatura Pt-100).

Despreciando las especies de los micronutrientes, la alcalinidad viene dada por

$$
\mathrm{A}_{\mathrm{T}}=\left[\mathrm{HCO}_{3}^{-}\right]+2 \cdot\left[\mathrm{CO}_{3}^{-}\right]+\left[\mathrm{B}(\mathrm{OH})_{4}^{-}\right]+\left[\mathrm{OH}^{-}\right]-\left[\mathrm{H}^{+}\right]
$$

where $\left[\mathrm{H}^{+}\right]$includes the associated species with fluoride and sulfate ions ( $\mathrm{HF}$ and $\mathrm{HSO}_{4}^{-}$).

According to Skirrow (1975): donde $\left[\mathrm{H}^{+}\right]$incluye las especies asociadas con los iones fluoruro y sulfato ( $\mathrm{HF}$ y $\mathrm{HSO}_{4}^{-}$).

Según (Skirrow, 1975):

$$
\mathrm{C}_{\mathrm{T}}=\left(\mathrm{A}_{\mathrm{T}}+\mathrm{D}\right) \cdot \mathrm{E}
$$

where $\mathrm{D}$ and $\mathrm{E}$ are the following expressions

donde D y E son las siguientes expresiones

$$
\mathrm{D}=\frac{\mathrm{a}_{\mathrm{H}}^{\prime}}{\mathrm{f}_{\mathrm{H}}^{\mathrm{T}}}-\frac{\mathrm{B}_{\mathrm{T}} \cdot \mathrm{K}_{\mathrm{B}}^{\prime}}{\mathrm{K}_{\mathrm{B}}^{\prime}+\mathrm{a}_{\mathrm{H}}^{\prime}}-\frac{\mathrm{K}_{\mathrm{W}} \cdot \mathrm{f}_{\mathrm{H}}^{\mathrm{T}}}{\mathrm{a}_{\mathrm{H}}^{\prime}}
$$

and

$$
\mathrm{E}=\frac{1+\left(\mathrm{a}_{\mathrm{H}}^{\prime} / \mathrm{K}_{1}^{\prime}\right)+\left(\mathrm{K}_{2}^{\prime} / \mathrm{a}_{\mathrm{H}}^{\prime}\right)}{1+\left(2 \cdot \mathrm{K}_{2}^{\prime} / \mathrm{a}_{\mathrm{H}}\right)}
$$


where $\mathrm{a}_{\mathrm{H}}$ and $\mathrm{f}_{\mathrm{H}}{ }^{\mathrm{T}}$ are the apparent activity of the hydrogen ions and the activity coefficient, respectively; $\mathrm{f}_{\mathrm{H}}{ }^{\mathrm{T}}$ was determined by Mehrbach et al. (1973) and parameterized by Pérez and Fraga (1987b). $\mathrm{B}_{\mathrm{T}}$ is the boron concentration in seawater estimated from salinity (Whitfield and Jagner, 1981). Regarding the equilibrium constants used: $\mathrm{K}_{1}^{\prime}$ is given by Mehrbach et al. (1973); $\mathrm{K}_{2}^{\prime}$ by Roy et al. (1996), adapted using $\mathrm{f}_{\mathrm{H}}{ }^{\mathrm{T}}$ of Mehrbach et al. (1973); $\mathrm{K}_{\mathrm{B}}{ }^{\prime}$ by Dickson (1990); and $\mathrm{K}_{\mathrm{W}}{ }^{\prime}$ by Dickson and Riley (1979). As only $\mathrm{K}_{1}{ }^{\prime}$ has a significant influence on the calculated $\mathrm{A}_{\mathrm{T}}$, an error of 0.01 in $\mathrm{pK}_{1}{ }^{\prime}$ causes an error of $0.05 \%$ in $\mathrm{A}_{\mathrm{T}}$.

As there is no loss of $\mathrm{CO}_{2}$ during the quick alkalinity titration, the following expression is obtained by equalizing the initial and final amount of $\mathrm{C}_{\mathrm{T}}$ : donde $\mathrm{a}_{\mathrm{H}} \mathrm{y} \mathrm{f}_{\mathrm{H}}{ }^{\mathrm{T}}$ son la actividad aparente de los hidrogeniones y el coeficiente de actividad, respectivamente; $\mathrm{f}_{\mathrm{H}}{ }^{\mathrm{T}}$ fue determinado por Mehrbach et al. (1973) y parametrizado por Pérez y Fraga (1987b). $B_{\Gamma}$ es la concentraciónde boro en agua de mar, estimada a partir de la salinidad (Whitfield y Jagner, 1981). Las constantes de equilibrio utilizadas son: $\mathrm{K}_{1}^{\prime}$ de Mehrbach et al. (1973); $\mathrm{K}_{2}^{\prime}$ de Roy et al. (1996), adaptada a la escala NBS con $\mathrm{f}_{\mathrm{H}}^{\mathrm{T}}$; $\mathrm{K}_{\mathrm{B}}{ }^{\prime}$ de Dickson (1990); y $\mathrm{K}_{\mathrm{w}}{ }^{\prime}$ de Dickson y Riley (1979). Únicamente $\mathrm{K}_{1}{ }^{\prime}$ tiene una influencia significativa en la $\mathrm{A}_{\mathrm{T}}$ calculada; un error en el $\mathrm{pK}_{1}{ }^{\prime}$ de 0.01 causa un error de $0.05 \%$ en la $\mathrm{A}_{\mathrm{T}}$.

Igualando la cantidad de $\mathrm{C}_{\mathrm{T}}$ final e inicial de la valoración ya que no existe pérdida de $\mathrm{CO}_{2}$, se obtiene la siguiente expresión:

$$
A_{T}=N_{H C l} \cdot V_{H C l} / W+\frac{D_{f} \cdot E_{f} \cdot\left(1+V_{H C l} / W\right)-E_{i} \cdot\left(D_{i}+N_{H C l} \cdot V_{H C l} / W\right)}{E_{i}-E_{j}}
$$

where $i$ and $f$ are the initial and final values of the titration, and $\mathrm{V}_{\mathrm{HCl}}$ is the average volume of the $\mathrm{HCl}$ solution added at the two end points. The initial $\mathrm{pH}$ was taken from a $\mathrm{pH}$ sample measured by potentiometric or spectrophotometric techniques. $\mathrm{N}_{\mathrm{HCl}}$ is the molarity of the $\mathrm{HCl}$ solution $(0.1 \mathrm{M}$, see below). In equations (3) and (4) the final $\mathrm{pH}$ value used is an average of the $\mathrm{pH}$ obtained at the two end points. $\mathrm{W}$ is the mass of the sample calculated as a function of salinity and temperature. All the equations and procedures are formulated in the $\mathrm{pH}$ NBS scale in order to assure the use of this method at any temperature and in any type of water. Conversion to the SWS scale can be carried out using the appropriate dissociation constants on SWS scale and replacing $\mathrm{f}_{\mathrm{H}}{ }^{\mathrm{T}}$ by 1 at $25^{\circ} \mathrm{C}$. donde $i$ y $f$ son los valores inicial y final de la valoración, y $\mathrm{V}_{\mathrm{HCl}}$ es el volumen medio de $\mathrm{HCl}$ añadido en los dos puntos finales. $\mathrm{El} \mathrm{pH}$ inicial de la muestra se toma de una medida de éste mediante potenciometría o con una técnica espectrofotométrica. $\mathrm{N}_{\mathrm{HCl}}$ es la molaridad de la disolución ácida (0.1M, ver más abajo). En las ecuaciones (3) y (4) el pH final utilizado es la media de los $\mathrm{pH}$ obtenidos en los dos puntos finales de la valoración. W es la masa de la muestra calculada en función de la temperatura y de la salinidad. Todas las ecuaciones y procedimientos se formulan en escala NBS de $\mathrm{pH}$, permitiendo así su uso en cualquier tipo de agua y rango de temperaturas. La conversión a escala SWS es directa utilizando las correspondientes constantes de disociación en escala SWS y reemplazando $\mathrm{f}_{\mathrm{H}}^{\mathrm{T}}$ por 1 a $25^{\circ} \mathrm{C}$. 
Ciencias Marinas, Vol. 26, No. 3, 2000

\section{Hydrochloric acid}

The 0.1 molar $\mathrm{HCl}$ was quickly prepared diluting 0.5 moles (18.231 g) $\mathrm{HCl}$ (\#61710, Riedel de Haën, Seelze, Germany) with highpurity deionized water in a $5000 \pm 0.5 \mathrm{~mL}$ calibrated and graduated volumetric flask. This is used as a storing receptacle avoiding any transfer. The nominal molarity for the $\mathrm{HCl}$ solution used in all the experiments made was 0.10020 at $20^{\circ} \mathrm{C}$. This molarity was verified titrating $20 \mathrm{~mL}$ of $\mathrm{Na}_{2} \mathrm{CO}_{3}(0.01412 \mathrm{M})$ to a final $\mathrm{pH}_{\mathrm{NBS}}$ of 4.25. The $\mathrm{Na}_{2} \mathrm{CO}_{3}$ volume was measured with a Metrohm burette calibrated gravimetrically at laboratory temperature. The $\mathrm{HCl}$ titration gave a molarity of $0.10019 \pm$ $0.00003(n=7)$. All volumes were referred to $20^{\circ} \mathrm{C}$.

\section{Phthalate-borax 4.4 buffers in seawater}

An amount of $4.085 \mathrm{~g}$ of analytical grade $\mathrm{C}_{8} \mathrm{H}_{5} \mathrm{O}_{4} \mathrm{~K}$ (Merck, Darmstadt, Germany) and $1.5257 \mathrm{~g}$ of analytical grade $\mathrm{B}_{4} \mathrm{O}_{7} \mathrm{Na}_{2} \cdot 10 \mathrm{H}_{2} \mathrm{O}$ (Merck, Darmstadt, Germany) were dissolved in $1 \mathrm{~L}$ of neutralized and $\mathrm{CO}_{2}$-free natural seawater, which was obtained from seawater already titrated and bubbled with $\mathrm{N}_{2}$.

\section{RESULTS}

In order to obtain a relationship between temperature and $\mathrm{pH}_{\mathrm{NBS}}$ for the 4.4 buffer solution used to calibrate the electrode, independent spectrophotometric $\mathrm{pH}$ measurements were made using bromocresol green (BCG) following Breland and Byrne (1993). These authors provided $\mathrm{pH}$ on the free molal scale $\left(\mathrm{pH}_{\mathrm{fm}}\right)$ as a function of BCG absorbance ratio

\section{Disolución de ácido clorhídrico}

La disolución 0.1 molar de $\mathrm{HCl}$ se prepara rápidamente diluyendo 0.5 moles $(18.231 \mathrm{~g})$ de $\mathrm{HCl}$ (\#61710, Riedel de Haën, Seelze, Alemania) con agua pura desionizada en un matraz volumétrico de $5000 \pm 0.5 \mathrm{~mL}$, calibrado y graduado. Éste se utiliza a su vez como recipiente almacén, evitando así traspasos. La molaridad nominal de la disolución de $\mathrm{HCl}$ utilizada en todos los experimentos fue 0.10020 a $20^{\circ} \mathrm{C}$. Ésta se verificó valorando $20 \mathrm{~mL}$ de $\mathrm{Na}_{2} \mathrm{CO}_{3}(0.01412 \mathrm{M})$ hasta un final de 4.25. El volumen de $\mathrm{Na}_{2} \mathrm{CO}_{3}$ se determinó con una bureta Metrohm calibrada gravimétricamente a temperatura de laboratorio. La molaridad de la disolución ácida obtenida de este modo fue $0.10019 \pm 0.00003(n=7)$. Todos los volúmenes se refieren a $20^{\circ} \mathrm{C}$.

\section{Disolución tampón 4.4 de ftalato-bórax en agua de mar}

Se disolvieron $4.085 \mathrm{~g}$ de $\mathrm{C}_{8} \mathrm{H}_{5} \mathrm{O}_{4} \mathrm{~K}$ de alta calidad (Merck, Darmstadt, Alemania) y $1.5257 \mathrm{~g}$ de $\mathrm{BO}_{4} \mathrm{Na}_{2} \cdot 10 \mathrm{H}_{2} \mathrm{O}$ de alta calidad (Merck, Darmstadt, Alemania) en $1 \mathrm{~L}$ de agua de mar natural neutralizada y $\sin \mathrm{CO}_{2}$, que se obtuvo a partir de agua de mar ya valorada y burbujeada con $\mathrm{N}_{2}$.

\section{RESULTADOS}

La variación con la temperatura del $\mathrm{pH}_{\mathrm{NBS}}$ de la disolución tampón 4.4, utilizada en la calibración del electrodo, se obtuvo realizando medidas espectrofotométricas de $\mathrm{pH}$ con verde de bromo cresol (BCG) siguiendo la técnica propuesta por Breland y Byrne (1993). Estos autores proporcionan una ecuación para obtener el $\mathrm{pH}$ en escala libre y molal $\left(\mathrm{pH}_{\mathrm{fm}}\right)$ como 
$\left(\mathrm{R}(\mathrm{t})={ }_{616} \mathrm{~A} /{ }_{444} \mathrm{~A}\right)$ at a given temperature $(\mathrm{T}$ in ${ }^{\circ} \mathrm{C}$ ) and salinity $(\mathrm{S})$ as: función del cociente de absorbancias a dos longitudes de onda $\left(\mathrm{R}(\mathrm{t})={ }_{616} \mathrm{~A} /{ }_{444} \mathrm{~A}\right)$ a una temperatura dada $\left(\mathrm{T}\right.$ en $\left.{ }^{\circ} \mathrm{C}\right)$ y salinidad $(\mathrm{S})$ :

$$
\mathrm{pH}_{\mathrm{fm}}=-\log \left[\mathrm{H}^{+}\right]_{\mathrm{f}}=\log \beta_{1}+\log \{[\mathrm{R}(25)-0.00131] /[2.3148-0.1299 \mathrm{R}(25)]\}
$$

where

donde

$$
\begin{gathered}
\mathrm{R}(25)=\mathrm{R}(\mathrm{t})[1+0.00907(25-\mathrm{T})] \\
\log _{\mathrm{I}} \beta_{1}=4.4166+\left(5.946 \cdot 10^{-4}\right) \cdot(35-\mathrm{S})
\end{gathered}
$$

These factors correct deviations from $25^{\circ} \mathrm{C}$ and salinity effect on the indicator dissociation constant.

Measured values of $\mathrm{pH}_{\mathrm{f}}$ as a function of temperature are shown in table 1 . Conversion of $\mathrm{pH}_{\mathrm{f}}$ to the NBS scale was done using the apparent activity coefficient $\left(\mathrm{f}_{\mathrm{H}}\right)$ defined previously. The $\mathrm{pH}$ values obtained can be used to calibrate the $\mathrm{pH}$ electrode close to the equivalent end point at any $\mathrm{pH}$ scale and in the same ionic media than the oceanic samples. If the combined electrode is calibrated with a 7.413 phosphate buffer at the NBS scale, it yields a $\mathrm{pH}_{\mathrm{NBS}}$ value for the phthalate-borax buffer of $4.426 \pm 0.013$ at $25^{\circ} \mathrm{C}$, which is 0.013 higher than that estimated by spectrophotometric BCG measurements (4.413, see table 1$)$. These high $\mathrm{pH}$ values are probably due to problems of the direct potentiometric methods related to the liquid-junction potential of the reference electrode (Whitfield and Jagner, 1981; Dickson, 1984; Millero, 1995). In addition, if the combined electrode is calibrated with a phthalate $4.008 \mathrm{NBS}$ buffer the $\mathrm{pH}_{\mathrm{NBS}}$ recorded was $4.392 \pm 0.012$ at $25^{\circ} \mathrm{C}(n=35)$. Despite these differences in the absolute value of the 4.4 buffer solution $\mathrm{pH}_{\mathrm{NBS}}$, the thermal change both calibrating the electrode with the 7.413 or 4.008 buffer solution is very similar, $-0.007 \pm 0.001$ from $20^{\circ} \mathrm{C}$ to $30^{\circ} \mathrm{C}$,
Estos factores corrigen los efectos de la salinidad sobre la constante de disociación del indicador y la normalizan a $25^{\circ} \mathrm{C}$.

En la tabla 1 se muestra la variación de los valores de $\mathrm{pH}_{\mathrm{f}}$ con la temperatura. El cambio de escala de NBS a total se realizó utilizando el coeficiente de actividad aparente $\left(\mathrm{f}_{\mathrm{H}}\right)$ definido anteriormente. Los valores de $\mathrm{pH}$ obtenidos, expresados en cualquiera de las escalas, se pueden utilizar para calibrar el electrodo en un $\mathrm{pH}$ muy cercano al punto final de valoración, con la ventaja añadida de que se realiza en el mismo medio iónico que las muestras de agua de mar. Calibrando el electrodo combinado con un tampón fosfato de $\mathrm{pH}_{\mathrm{NBS}} 7.413$, éste proporciona valores de $\mathrm{pH}_{\mathrm{NBS}}$ para el tampón de ftalato-bórax de $4.426 \pm 0.013$ a $25^{\circ} \mathrm{C}$, que es 0.013 unidades mayor que los valores de $\mathrm{pH}$ estimados mediante espectrofotometría (4.413, ver tabla 1). Esto puede deberse muy probablemente a los típicos problemas de los métodos potenciométricos directos, como son variaciones en el potencial de unión líquida del electrodo de referencia (Whitfield y Jagner, 1981; Dickson, 1984; Millero, 1995). Por otro lado, si el electrodo combinado se calibra con una disolución tampón 4.008 NBS de ftalato, el $\mathrm{pH}_{\mathrm{NBS}}$ medido en el tampón de 4.4 es de $4.392 \pm 0.012$ a $25^{\circ} \mathrm{C}(n=35)$. La variación con la temperatura del $\mathrm{pH}_{\mathrm{NBS}}$ del tampón 4.4 tanto calibrando el electrodo con el tampón 7.413 o 
Ciencias Marinas, Vol. 26, No. 3, 2000

Table 1. Average (X), standard deviation (SD) and number of measurements $(n)(X+\mathrm{SD}(n))$ of the spectrophotometric $\mathrm{pH}$ determinations of the phthalate-borax 4.4 buffer solution as a function of temperature $(\mathrm{T})$. Spectrophotometric $\mathrm{pH}$ was determined using bromocresol green (BCG), and expressed in molar and free hydrogen scale $\left(\mathrm{pH}_{\mathrm{f}} \mathrm{BCG}\right)$ according to Breland and Byrne (1993). The $\mathrm{pH}_{\mathrm{f}} \mathrm{BCG}$ is converted to the NBS $\left(\mathrm{pH}_{\mathrm{NBS}}\right)$ scale. $\mathrm{S}$ stands for salinity. A linear relationship was obtained between $\mathrm{pH}_{\mathrm{NBS}}$ and temperature.

Tabla 1. Media (X), desviación estándar (SD) y número de medidas $(n)(\mathrm{X}+\mathrm{SD}(n))$ de las lecturas espectrofotométricas del $\mathrm{pH}$ de la disolución tampón 4.4 de ftalato-bórax a distintas temperaturas (T). El pH espectrofotométrico se determinó usando verde de bromo cresol (BCG) y se expresa en escala libre molar $\left(\mathrm{pH}_{\mathrm{f}} \mathrm{BCG}\right)$ según Breland y Byrne (1993). El $\mathrm{pH}_{\mathrm{f}} \mathrm{BCG}$ se convirtió a la escala NBS $\left(\mathrm{pH}_{\mathrm{NBS}}\right)$. S es la salinidad. Se obtuvo una relación lineal entre el $\mathrm{pH}_{\mathrm{NBS}}$ y la temperatura.

\begin{tabular}{ccccc}
\hline $\mathrm{T}\left({ }^{\circ} \mathrm{C}\right)$ & $\mathrm{S}$ & $\mathrm{pH}_{\mathrm{f}} \mathrm{BCG}$ & $\mathrm{pH}_{\mathrm{Sws}}$ & $\mathrm{pH}_{\mathrm{NBS}}$ \\
\hline 20 & 35.184 & $4.3946 \pm 0.0003(4)$ & 4.2668 & 4.4164 \\
23 & 35.184 & $4.3904 \pm 0.0001(3)$ & 4.2542 & 4.4141 \\
25 & 35.184 & $4.3878 \pm 0.0002(4)$ & 4.2456 & 4.4128 \\
27 & 35.184 & $4.3854 \pm 0.0001(3)$ & 4.2366 & 4.4117 \\
30 & 35.184 & $4.3853 \pm 0.0002(4)$ & 4.2239 & 4.4105 \\
\hline
\end{tabular}

$\mathrm{pH}_{\mathrm{NBS}}=4.413 \pm 0.001-(0.00059 \pm 0.00005) \cdot(\mathrm{T}-25)$

$r^{2}=0.98, P<0.001$

which is very close to that obtained using spectrophotometric BCG measurements (see table 1).

Therefore, the potentiometric technique proposed by Pérez and Fraga (1987a) was improved by direct calibration of the combined electrode near the end point with a phthalate-borax 4.4 buffer solution. In order to evaluate the efficacy of this improvement and check the precision and accuracy of the method, a series of routine seawater measurements was planned during one month. After calibrating the combined electrode with the 4.4 buffer and table 1 , the sequence of analysis was the following: (i) about four samples of any seawater to reach a stable operative mode; (ii) four to six samples of substandard seawater (SWSTD), this water was stabilized in a 25 -L container a few days con el de 4.008 es muy similar, $-0.007 \pm 0.001$ de $20^{\circ} \mathrm{C}$ a $30^{\circ} \mathrm{C}$, valor muy cercano al obtenido utilizando medidas espectrofotométricas (ver tabla 1).

Por tanto, el método potenciométrico propuesto por Pérez y Fraga (1987a) se mejora mediante la calibración directa del electrodo combinado cerca del punto final de la valoración usando un tampón 4.4 de ftalato-bórax. La eficacia de esta mejora, así como la precisión y exactitud del método se comprobaron a lo largo de un mes realizando una serie de análisis rutinarios de alcalinidad en agua de mar. Después de calibrar el electrodo con el tampón de 4.4 usando la tabla 1, el protocolo de análisis fue el siguiente: (i) sobre unas cuatro muestras de cualquier agua de mar superficial hasta que se estabilicen y reproduzcan las medidas; (ii) de cuatro a seis muestras de agua de mar subestándar (SWSTD), esta agua se estabiliza en un 
Pérez et al.: Improvements in a fast potentiometric seawater alkalinity determination

before the analysis; (iii) two or three titrations of CRM samples, in this case two batches of CRM were used during the experiments (batch 33 and 37, with a certified alkalinity of 2234.9 and $2314.1 \mu \mathrm{molkg}^{-1}$, respectively). All the samples were previously stabilized at laboratory temperature in an interval lower than $0.1^{\circ} \mathrm{C}$. Table 2 shows the typical sequence of alkalinity measurements in each batch of analysis.

For each experiment the average alkalinity and standard deviation of the CRM and SWSTD samples were calculated (table 3). Combining the 18 experiments carried out, the mean standard deviation of the CRM and SWSTD analyses were 0.5 and $0.8 \mu \mathrm{molkg}^{-1}$, respectively. The correction factor for the CRM analyses calculated as the ratio between the measured and certified alkalinity varied from 0.9979 to 1.002 , with an average of $0.9996 \pm 0.0011$. This small variability stemmed mainly from variations in the electrode calibrations.

The average SWSTD alkalinity measured was $2290.2 \pm 2.3 \mu \mathrm{molkg}^{-1}$, which represents a standard error of $0.1 \%$. However, if we take into account the correcting CRM factor, the average SWSTD alkalinity (SWSTDcor column in table 3) was $2291.1 \pm 1.4 \mu$ molkg-sw $^{-1}$, representing a standard error of $0.06 \%$.

The actual SWSTD alkalinity is not perfectly constant because of the continuous drawing of seawater during the 24 days of the series of experiments. So, corrected SWSTD alkalinity (SWSTDcor) presented a slight trend with time, which can be linearly adjusted to the equation: contenedor de 25 L unos días antes de los análisis; (iii) dos o tres muestras de CRM, en este caso se analizaron dos lotes distintos de este material (lote 33 y 37, con valores de alcalinidad certificados de 2234.9 y $2314.1 \mu \mathrm{mol} \mathrm{kg} \mathrm{kg}^{-1}$, respectivamente). Todas las muestras se estabilizaron previamente a la temperatura de laboratorio, con un margen menor que $0.1^{\circ} \mathrm{C}$. En la tabla 2 se muestra la secuencia de medias de alcalinidad por lote de análisis.

Para cada experimento se calculó la media y desviación estándar de las muestras de CRM y de SWSTD (tabla 3). Combinando la totalidad de los 18 experimentos llevados a cabo, se obtuvo una desviación estándar media de los análisis de CRM y SWSTD de 0.5 y $0.8 \mu \mathrm{molkg}^{-1}$, respectivamente. El factor de corrección de los análisis de CRM calculado como el cociente entre la alcalinidad medida y certificada varía entre 0.9979 y 1.002 , con un valor medio de $0.9996 \pm 0.00011$. Esta pequeña variación se puede atribuir principalmente a variaciones en la calibración del electrodo.

La alcalinidad media de las muestras de SWSTD fue de $2290.2 \pm 2.3 \mu \mathrm{molkg}^{-1}$, lo cual implica un error estándar de $0.1 \%$. Si se tiene en cuenta el factor de corrección obtenido con el CRM, el valor medio de las muestras de SWSTD (columna SWSTDcor en la tabla 3) pasa a ser $2291.1 \pm 1.4 \mu \mathrm{molkg}^{-1}$, lo cual reduce el error a $0.06 \%$.

La alcalinidad de SWSTD no se mantiene totalmente constante a lo largo de los 24 días de duración de la serie de experimentos debido a la continua toma de muestras de agua. De esta manera, la alcalinidad corregida de las muestras de SWSTD (SWSTDcor) presenta una ligera variación temporal que se puede ajustar linealmente con la ecuación:

$$
\begin{gathered}
\text { SWSTDcor }=(2292.5 \pm 0.5)-(0.11 \pm 0.03) \cdot \mathrm{T}(\text { day }) \\
r^{2}=0.39, n=18, P<0.006
\end{gathered}
$$


Ciencias Marinas, Vol. 26, No. 3, 2000

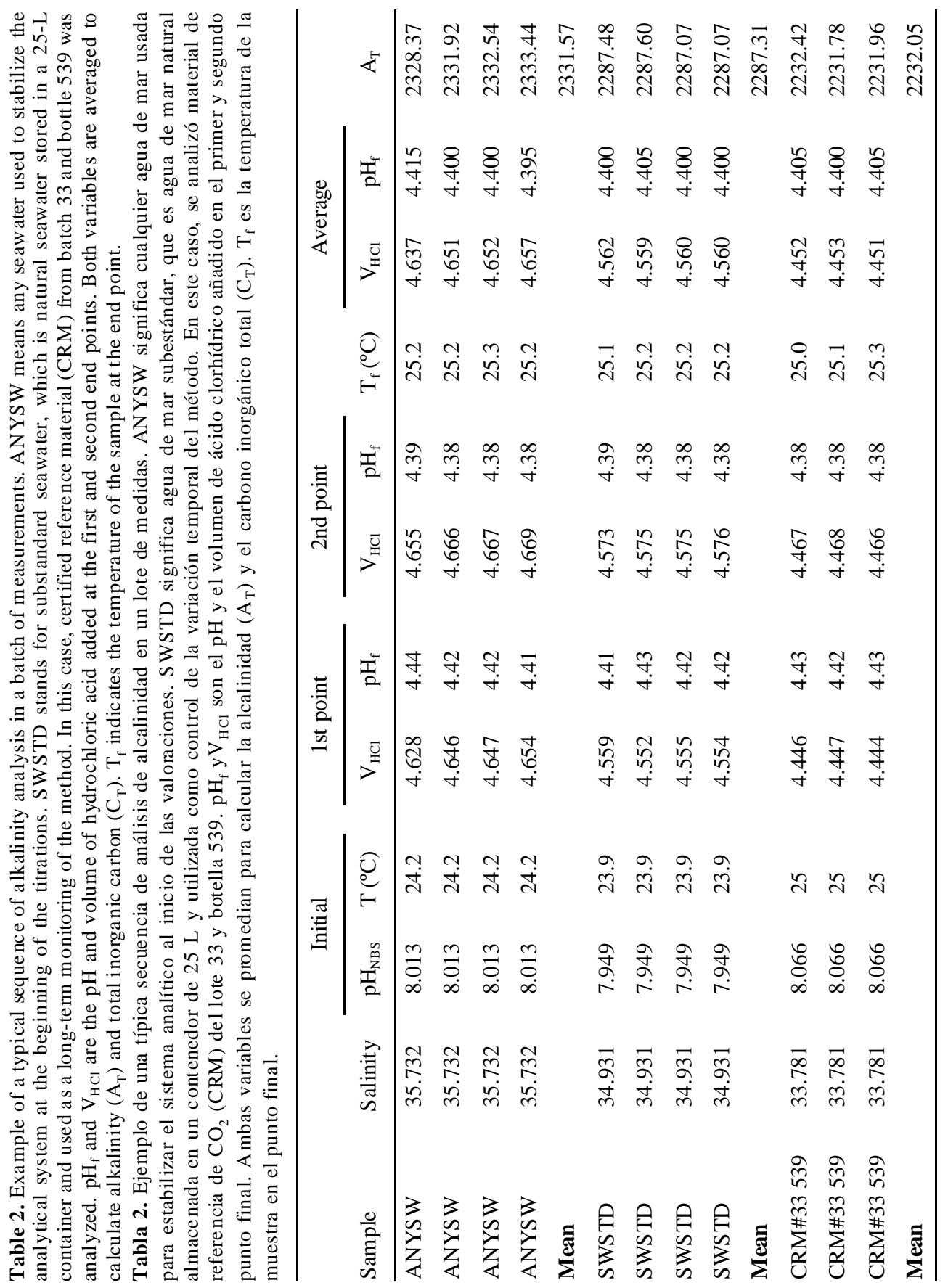


Pérez et al.: Improvements in a fast potentiometric seawater alkalinity determination

Table 3. Average alkalinity $\left(\mathrm{Alk}_{\mathrm{av}}\right.$ in $\mu$ molkg-sw ${ }^{-1}$ ) and standard deviation (SD) of the certified reference material (CRM) and substandard seawater (SWSTD) samples analyzed in the different batches of measurements done; $n$ stands for the number of samples in each average. f-CRM or CRM factor is the ratio between the measured and certified alkalinity (the certified alkalinities for CRM 33 and 37 were 2234.9 and $2314.1 \mu \mathrm{molkg}-\mathrm{SW}^{-1}$, respectively). SWSTDcor alkalinity stands for the average alkalinity of the SWSTD samples corrected for the CRM factor, i.e., SWSTD Alk ${ }_{\mathrm{av}}$ divided by f-CRM. The residuals of the linear fit of SWSTDcor alkalinity with time (Resd) are also shown.

Tabla 3. Alkalinidad media ( $\mathrm{Alk}_{\mathrm{av}}$ en $\mu$ molkg-sw ${ }^{-1}$ ) y desviación estándar (SD) de las muestras de material de referencia certificado (CRM) y agua de mar subestándar (SWSTD) analizadas en los diferentes lotes de medidas llevadas a cabo; $n$ es el número de muestras de cada media. f-CRM o factor CRM es el cociente entre la alcalinidad medida y la certificada (los lotes de CRM analizados fueron el 33 y el 37, con una alcalinidad certificada de 2234.9 y $2314.1 \mu$ molkg-sw ${ }^{-1}$, respectivamente). SWSTDcor es la alcalinidad media de las muestras de SWSTD corregida con el factor CRM, i.e., SWSTD Alk ${ }_{\mathrm{av}}$ dividida por f-CRM. Se muestran también los residuos del ajuste lineal de SWSTDcor frente al tiempo (Resd).

\begin{tabular}{|c|c|c|c|c|c|c|c|c|c|c|}
\hline \multirow[b]{2}{*}{ Day } & \multicolumn{5}{|c|}{ CRM } & \multicolumn{3}{|c|}{ SWSTD } & \multicolumn{2}{|c|}{ SWSTDcor } \\
\hline & Batch & $\mathrm{Alk}_{\mathrm{av}}$ & $\mathrm{SD}$ & $n$ & f-CRM & $\mathrm{Alk}_{\mathrm{av}}$ & SD & $n$ & Alk & Resd \\
\hline 1 & 33 & 2239.3 & 1.2 & 4 & 1.00198 & 2296.7 & 1.5 & 6 & 2292.2 & -0.2 \\
\hline 2 & 33 & 2232.9 & 0.4 & 2 & 0.99909 & 2290.8 & 0.5 & 6 & 2292.9 & 0.6 \\
\hline 3 & 33 & 2232.8 & 0.2 & 2 & 0.99904 & 2290.8 & 0.8 & 6 & 2293.0 & 0.9 \\
\hline 4 & 33 & 2232.2 & & 1 & 0.99878 & 2289.2 & 1.0 & 4 & 2292.0 & 0.0 \\
\hline 7 & 33 & 2232.8 & 1.2 & 3 & 0.99904 & 2289.6 & 1.0 & 4 & 2291.8 & -0.0 \\
\hline 8 & 33 & 2233.6 & 0.7 & 6 & 0.99943 & 2290.3 & 1.0 & 4 & 2291.6 & -0.0 \\
\hline 9 & 33 & 2230.3 & 0.0 & 3 & 0.99795 & 2286.9 & 0.7 & 4 & 2291.6 & 0.1 \\
\hline 10 & 33 & 2231.9 & 0.3 & 2 & 0.99867 & 2288.7 & 0.5 & 4 & 2291.7 & 0.4 \\
\hline 11 & 33 & 2234.6 & 0.5 & 3 & 0.99985 & 2290.4 & 2.0 & 4 & 2290.7 & -0.5 \\
\hline 14 & 33 & 2232.1 & 0.3 & 3 & 0.99872 & 2287.3 & 0.2 & 4 & 2290.2 & -0.8 \\
\hline 15 & 33 & 2240.2 & 0.5 & 3 & 1.00235 & 2294.1 & 0.2 & 4 & 2288.7 & -2.2 \\
\hline 16 & 33 & 2233.0 & 0.3 & 3 & 0.99916 & 2289.8 & 0.4 & 3 & 2291.7 & 1.0 \\
\hline 17 & 33 & 2235.1 & 0.6 & 3 & 1.00007 & 2288.4 & 0.6 & 4 & 2288.3 & -2.3 \\
\hline 18 & 37 & 2315.9 & 0.3 & 2 & 1.00076 & 2292.7 & 0.5 & 4 & 2290.9 & 0.5 \\
\hline 21 & 37 & 2311.6 & 0.6 & 3 & 0.99893 & 2289.3 & 0.5 & 4 & 2291.7 & 1.5 \\
\hline 22 & 37 & 2312.0 & 0.3 & 3 & 0.99911 & 2289.7 & 1.5 & 4 & 2291.7 & 1.6 \\
\hline 23 & 37 & 2315.5 & 0.6 & 3 & 1.00060 & 2291.4 & 1.2 & 4 & 2290.0 & 0.0 \\
\hline 24 & 37 & 2313.3 & 0.7 & 3 & 0.99963 & 2288.6 & 0.8 & 4 & 2289.4 & -0.4 \\
\hline Average & & & 0.5 & & 0.99962 & 2290.2 & 0.8 & & 2291.1 & -0.00 \\
\hline $\begin{array}{l}\text { SD } \\
\text { Error }\end{array}$ & & & 0.3 & & 0.00112 & 2.3 & 0.5 & & $\begin{array}{r}1.4 \\
0.06 \%\end{array}$ & $\begin{array}{l}1.0 \\
0.04 \%\end{array}$ \\
\hline
\end{tabular}


Ciencias Marinas, Vol. 26, No. 3, 2000

If alkalinity SWSTD measurements are corrected for this low temporal drift, the final and absolute standard error of the new methodology is reduced to $0.04 \%$ (table 3 ). Thus, following this method, any stabilized seawater can be used as a standard for alkalinity measurements together with CRM.

\section{DISCUSSION}

Both potentiometric and spectrophotometric methods for alkalinity determination give a similar precision (about 2-6 $\mu \mathrm{molkg}^{-1}$ ) (Breland and Byrne, 1993; Millero et al., 1993a). However, the most known potentiometric methods (DOE, 1994) present some drawbacks; for example, they require experienced personnel for handling and each sample takes from 15 to 30 minutes. Furthermore, they are designed specifically for oceanic seawater using $\mathrm{HCl}$ with $\mathrm{NaCl}$ as titrant, which needs an additional determination of the alkalinity blank. In addition, these methodologies need thermostatic bath, cell volume calibrations, samples without trapped air or bubbles, no leaking or sticking pistons and flushing the cell several times with the sample before each titration (Millero et al., 1993a). Finally, the changing slope response of the $\mathrm{pH}$ electrode during the potentiometric titration produces a loss of accuracy in the $\mathrm{A}_{\mathrm{T}}$ and $\mathrm{C}_{\mathrm{T}}$ calculations (Millero et al., 1993a).

In this connection, the final $\mathrm{pH}$ in the alkalinity determination is measured with a precision of $0.002 \mathrm{pH}$ units, producing an error of $0.01 \%$ in the alkalinity titration, which is a quarter of the total error $(0.04 \%$, table 3$)$. Higher precisions in the final $\mathrm{pH}$ determination can be reached using spectrophotometry. However, the potentiometric control of $\mathrm{pH}$ during the titration is more effective, convenient and sufficiently precise.

The improvement proposed here in the potentiometric method for alkalinity described
Si esta tendencia temporal se elimina de las medidas de alcalinidad en las muestras de SWSTD, el error final y absoluto se reduce a $0.04 \%$ (tabla 3). Siguiendo esta metodología para la alcalinidad se puede utilizar cualquier agua de mar estabilizada como un estándar, junto con el CRM.

\section{DISCUSIÓN}

Tanto los métodos espectrofotométricos como los potenciométricos desarrollados para determinar la alcalinidad en agua de mar presentan una precisión similar (alrededor de 2 a $6 \mu \mathrm{molkg}^{-1}$ ) (Breland y Byrne, 1993; Millero et al., 1993a). A pesar de esto, los métodos potenciométricos más aceptados (DOE, 1994) muestran algunas desventajas, como por ejemplo, la necesidad de personal experimentado y la lentitud de los análisis (de 15 a 30 minutos); además, al estar diseñados específicamente para análisis en agua de mar utilizan $\mathrm{HCl}$ con $\mathrm{NaCl}$ como valorante, lo cual precisa de una determinación adicional de la alcalinidad blanco. Por otro lado, es necesario el uso de un baño termostático y el calibrado del volumen de las células, las muestras no deben contener aire ni burbujas, los émbolos no deben perder ni atascarse y se debe enjuagar varias veces la célula con la muestra antes de cada valoración (Millero et al., 1993a). Por último, el cambio temporal de la respuesta del electrodo durante la valoración provoca una pérdida en la exactitud de los cálculos de $\mathrm{A}_{\mathrm{T}}$ y $\mathrm{C}_{\mathrm{T}}$ (Millero et al., 1993a).

En este sentido, el valor del $\mathrm{pH}$ final de la valoración se determina con una precisión de 0.002 unidades de $\mathrm{pH}$, significando un error en la medida de alcalinidad de $0.01 \%$, que representa un cuarto del error total $(0.04 \%$, tabla 3$)$. Es posible alcanzar mayores precisiones en la medida del $\mathrm{pH}$ final usando métodos espectrofotométricos, aunque el control potenciométrico del pH a lo largo de la curva de valoración 
by Pérez and Fraga (1987a) combines the high accuracy of the spectrophotometric $\mathrm{pH}$ measurements over the 4.4 buffer, used to calibrate the electrode, and the ease of the potentiometric $\mathrm{pH}$ measurements along the titration curve. Recently, Ríos and Pérez (1999) improved the methodology proposed by Pérez and Fraga (1987a) by controlling the liquid junction potential by Culberson titrations and the use of surface seawater substandards. In this paper, changes in the Nerstian behaviour of the $\mathrm{pH}$ electrode or in the potential of the reference electrode do not affect the final $\mathrm{pH}$ determination, because calibrations were performed very close to the end point. In addition, the phthalate-borax 4.4 buffer can be used for calibration of the $\mathrm{pH}$ electrode on any $\mathrm{pH}$ scale (table 1), even in any other natural water apart from seawater using the $\mathrm{pH}$ NBS scale and knowing the equilibrium constants for carbonic acid.

Some other weak points of the alkalinity methodology proposed by DOE (1994) are the preparation and standardization of the $\mathrm{HCl}$ solution, and the high volume of sample needed for flushing the cell or flask. Regarding the $\mathrm{HCl}$ preparation, it is possible to avoid the $\mathrm{NaCl}$ addition by means of suitable algorithms (see material and methods section) that quantify the change of salinity at the end point. Millero et al. (1993a) reported alkalinity blanks of about $14 \mathrm{mM}$ due to $\mathrm{NaCl}$. The titrating $\mathrm{HCl}$ solution must be prepared with an error of about $0.1 \%$; both the diluted commercial $\mathrm{HCl}$ solutions and the procedure explained in the material and methods section for preparing and stabilizing the $\mathrm{HCl}$ allow a standardization with an error lower than $0.05 \%$.

Concerning the water sample requirements, in the potentiometric technique proposed in this work the seawater is neutralized $99 \%$ at least at the end point. Therefore, the few tiny droplets $(<2 \mathrm{~mL})$ that remain after draining the titrated sample do not affect the results of the following es más efectivo, cómodo y suficientemente preciso.

La mejora en el método de Pérez y Fraga (1987a) propuesta en este trabajo combina la precisión de las medidas de $\mathrm{pH}$ espectrofotométrico con la facilidad y rapidez de las medidas de $\mathrm{pH}$ potenciométrico, ya que el electrodo combinado se calibra cerca del punto final con medidas espectrofotométricas de $\mathrm{pH}$ sobre el tampón de 4.4 y la variación de $\mathrm{pH}$ a lo largo de la valoración se controla potenciométricamente. Recientemente, Ríos y Pérez (1999) mejoraron la metodología propuesta por Pérez y Fraga (1987a), al controlar mediante valoraciones Culberson y el uso de agua subestándar las variaciones en el potencial de unión líquida del electrodo; sin embargo, en el presente trabajo, los cambios en el comportamiento nerstiano del electrodo de $\mathrm{pH}$ o en el potencial del electrodo de referencia no afectan a la medida final de $\mathrm{pH}$, puesto que la calibración se llevó a cabo muy cerca del punto final de la valoración. Además, el tampón ftalato-bórax de 4.4 puede usarse para la calibración del electrodo en cualquier escala de $\mathrm{pH}$ (tabla 1), incluso en cualquier otra agua natural aparte del agua de mar, usando la escala NBS de pH y conociendo las constantes de equilibrio del sistema del carbónico.

Otros puntos débiles de la metodología de la alcalinidad propuesta en DOE (1994) son la preparación y estandarización de la disolución de $\mathrm{HCl}$, así como el gran volumen de muestra necesario para enjuagar la célula o matraz. Con respecto a la preparación del $\mathrm{HCl}$, es posible evitar la adición de $\mathrm{NaCl}$ utilizando las ecuaciones adecuadas (ver la sección de material y métodos) que cuantifiquen el cambio de la salinidad a punto final. Millero et al. (1993a) han llegado a determinar blancos en la disolución ácida de $14 \mathrm{mM}$ debido al $\mathrm{NaCl}$. La disolución valorante debe prepararse con un error de alrededor de $0.1 \%$; en realidad, ésta se puede preparar y estabilizar con un error menor 
Ciencias Marinas, Vol. 26, No. 3, 2000

sample, thus avoiding the routine washing of the cell or flask and reducing the sample volume required.

With all these advantages it is possible to analyze about 70-80 samples, 4 CRM and 6 SWSTD in 3.5 hours, which is three to five times faster than the spectrophotometric and whole potentiometric curve fitting titrations (Breland and Byrne, 1993; Millero et al. 1993a; Lee et al., 1997).

Finally, the use of CRM provided by A. Dickson (DOE, 1994) is a good test for the performance and reliability of the analysis and can be used to monitor and exclude systematic errors. The additional use of natural surface seawater practically without nutrients (SWSTD) complements the analysis during the course of a batch of measurements, saving CRM and ensuring the quality of data.

The effect of initial $\mathrm{pH}$ uncertainties on the calculated $\mathrm{C}_{\mathrm{T}}$ is 3.5 times higher than that caused by $\mathrm{A}_{\mathrm{T}}$ uncertainties (Johansson and Wedborg, 1982). Thus, spectrophotometric $\mathrm{pH}$ determinations, with a precision of \pm 0.0004 , become more suitable than the potentiometric ones for $\mathrm{G}$ (Millero, 1995). In this work, the estimated error in the improved potentiometric technique for alkalinity was $\pm 1 \mu \mathrm{molkg} \mathrm{k}^{-1}$. Millero et al. (1993b) and Millero (1995) showed an error transmission in $\mathrm{C}_{\mathrm{T}}$ of $\pm 3.8 \mu \mathrm{molkg}^{-1}$ when an accuracy of $\pm 4 \mu \mathrm{molkg}^{-1}$ in alkalinity is applied with the accuracy of spectrophotometric pH. Combining the accuracy of alkalinity obtained here $\left( \pm 1 \mu \mathrm{molkg} \mathrm{k}^{-1}\right)$ with spectrophotometric $\mathrm{pH}$ measurements, $\mathrm{C}_{\mathrm{T}}$ can be estimated with an error of $1.2 \mu \mathrm{molkg}^{-1}$, which is similar to that obtained using the coulometric method. In summary, the combination of the spectrophotometrically improved alkalinity technique, spectrophotometric $\mathrm{pH}$ determinations, and a good and suitable set of equilibrium constants provides a competitive and easy alternative to the coulometric method for $\mathrm{C}_{\mathrm{T}}$ determination. que $0.05 \%$ utilizando disoluciones de $\mathrm{HCl}$ disponibles en el mercado y siguiendo las indicaciones dadas en el apartado de material y métodos.

En lo referente a las necesidades de volumen de muestra, con la técnica potenciométrica propuesta en este trabajo el agua de mar se neutraliza en un $99 \%$, por lo menos hasta el punto final. Por lo tanto, las gotas de agua valorada $(<2 \mathrm{~mL})$ restantes después de vaciar la muestra no afectan al resultado del análisis siguiente. Esto evita el lavado rutinario de la célula o matraz y se reduce el volumen de muestra requerido.

Todas estas ventajas permiten el análisis de unas 70-80 muestras, 4 CRM y 6 SWSTD en unas 3.5 horas, lo cual es entre tres y cinco veces más rápido que las medidas espectrofotométricas o cualquiera de las valoraciones potenciométricas (Breland y Byrne, 1993; Millero et al., 1993a; Lee et al., 1997).

Por último, la utilización del material de referencia de $\mathrm{CO}_{2}$ suministrado por A. Dickson (DOE, 1994) es una forma excelente de comprobar el rendimiento y exactitud de los análisis y también puede ser utilizado para controlar y eliminar errores sistemáticos. Por añadido, el uso de agua de mar superficial prácticamente envejecida (SWSTD) complementa los análisis en cada lote de medidas, ahorrando CRM y asegurando la calidad de los datos.

El efecto sobre el $\mathrm{C}_{\mathrm{T}}$ calculado del valor del $\mathrm{pH}$ inicial de una muestra es 3.5 veces mayor que el provocado por la incertidumbre en el valor de $\mathrm{A}_{\mathrm{T}}$ (Johansson y Wedborg, 1982). Por lo tanto, la determinación espectrofotométrica del pH, con una precisión del 0.0004, resulta mucho más adecuada para $\mathrm{C}_{\mathrm{T}}$ que la potenciométrica (Millero, 1995). En este trabajo, el error estimado de la nueva técnica potenciométrica para la alcalinidad fue de $1 \mu \mathrm{molkg}^{-1}$. Millero et al. (1993b) y Millero (1995) muestran que el error transmitido a $\mathrm{C}_{\mathrm{T}}$ es de $\pm 3.8 \mu \mathrm{molkg}^{-1}$ cuando se aplica una exactitud 


\section{ACKNOWLEDGEMENTS}

This work was funded by the European Community, under grant MAST III CT960060, and by the Comisión Interministerial de Ciencia y Tecnología (CICYT), project number AMB 95 1084-CO3.

\section{REFERENCES}

Breland, J.A. and Byrne, R.H. (1993). Spectrophotometric determination of the total alkalinity of seawater using bromocresol green. Deep-Sea Res., 40: 629-641.

Clayton, T. and Byrne, R.H. (1993). Calibration of $\mathrm{m}$-cresol purple on the total hydrogen ion concentration scale and its application to $\mathrm{CO}_{2}$-system characterizations: Precision and thermodynamic consistency. Deep-Sea Res., Part I, 42: 411-429, 1995.

Culberson, C.H., Pytkowicz, R.M. and Hawley, J.E. (1970). Seawater alkalinity determination by the pH method. J. Mar. Res., 28: 15-21.

Dickson, A.G. (1981). An exact definition ot total alkalinty and procedure for the estimation of alkalinity and total inorganic carbon from titration data. Deep-Sea Res., 28(6): 609-623.

Dickson, A.G. (1984). pH scales and proton-transfer reactions in saline media such as seawater. Geochim. Cosmochim. Acta, 48: 2299-2308.

Dickson, A.G. (1990). Thermodynamics of the dissociation of boric acid in synthetic seawater from 273.15 to 318.15 K. Deep-Sea Res., 37: $755-766$.

Dickson, A.G. and Riley, J.P. (1979). The estimation of acid constants in seawater media from potentiometric titrations with strong base. I. The ionic product of seawater Kw. Mar. Chem., 7: 101-109.

DOE (1994). Handbook of methods for the analysis of the various parameters of the carbon dioxide system in seawater. Version 2. In: A.G. Dickson and C. Goyet (eds.), ORNL/CDIAC-74.

Johansson, O. and Wedborg, M. (1982). On the evaluation of potentiometric titrations of seawater with hydrochloric acid. Oceanol. Acta, 65: 363-373. de $\pm 4 \mu \mathrm{molkg}^{-1}$ en alcalinidad con medidas de $\mathrm{pH}$ espectrofotométrico. Combinando la exactitud de la alcalinidad aquí obtenida $\left( \pm 1 \mu \mathrm{molkg} \mathrm{k}^{-1}\right)$ con medidas de $\mathrm{pH}$ espectrofotométrico se puede determinar $\mathrm{C}_{\mathrm{T}}$ con un error de $\pm 1.2 \mu \mathrm{molkg}^{-1}$, valor similar al obtenido con el método coulométrico. En resumen, combinando nuestra técnica potenciométrica para la alcalinidad, medidas espectrofotométricas de $\mathrm{pH}$ y un buen y adecuado grupo de ecuaciones termodinámicas se obtiene una alternativa a la determinación coulométrica de $\mathrm{C}_{\mathrm{T}}$ competitiva y fácil.

\section{AGRADECIMIENTOS}

Este trabajo fue financiado por la Comunidad Europea, proyecto MAST III CT960060, y por la Comisión Interministerial de Ciencia y Tecnología (CICYT), código del proyecto AMB 95 1084-CO3.

Traducido al español por los autores.

Johnson, K.M., Wills, K.D., Butler, D.B., Johnson, W.K. and Wong, C.S. (1993). Coulometric total carbon dioxide analysis for marine studies: Maximizing the performance of an automated gas extraction system and coulometric detector. Mar. Chem., 44: 267-187.

Körzinger, A., Thomas, H., Scheider, B., Gronau, N., Mintrop, L. and Duinker, J.C. (1996). At-sea intercomparison of two newly designed underway $\mathrm{pCO}_{2}$ systems: Encouraging results. Mar. Chem., 52: 133-145.

Lee, K., Millero, F.J. and Wanninkhof, R. (1997). The carbon dioxide system in the Atlantic Ocean. J. Geophys. Res., 102(C7): 15693-15707.

Mehrbach, C., Culberson, C.H., Hawley, J.E. and Pytkowicz, R.M. (1973). Measurements of the apparent dissociation constants of carbonic in seawater at atmospheric pressure. Limnol. Oceanogr., 18: 897-907. 
Ciencias Marinas, Vol. 26, No. 3, 2000

Millero, F.J. (1995). Thermodynamics of the carbon dioxide system in the oceans. Geochim. Cosmochim. Acta, 59(4): 661-677.

Millero, F.J., Zhang, J.Z., Lee, K. and Campbell, D.M. (1993a). Titration alkalinity of seawater. Mar. Chem., 44: 153-165.

Millero, F.J, Byrne, R.H., Wanninkhof, R., Freely, R., Clayton, T., Murphy, P. and Lamb, M.F. (1993b). The internal consistency of $\mathrm{CO}_{2}$ measurements in the equatorial Pacific. Mar. Chem., 44: 269-280.

Pérez, F.F. and Fraga, F. (1987a). A precise and rapid analytical procedure for alkalinity determination. Mar. Chem., 21: 169-182.

Pérez, F.F. and Fraga, F. (1987b). The pH measurements in seawater on NBS scale. Mar. Chem., 21: 315-327.

Ríos, A.F. and Pérez, F.F. (1999). Improvements in potentiometric determinations of the $\mathrm{CO}_{2}$ oceanic system using seawater sub-standards and $\mathrm{CO}_{2}$ reference material. Ciencias Marinas, 25(1): 31-49.

Roy, R.N., Roy, L.N., Lawson, M., Vogel, K.M., Porter-Moore, C., Davis, W., Millero, F.J. and Campbell, D.M. (1996). The dissociation constants of carbonic acid in seawater at salinities 5 to 45 and temperatures 0 to $40^{\circ} \mathrm{C}$. Mar. Chem., 52: 183.

Skirrow, G. (1975). The dissolved gases: Carbon dioxide. 2nd ed. In: J.P. Riley and G. Skirrow (eds.), Chemical Oceanography. Academic Press, New York, pp. 1-81.

Wanninkhof, R. and Thoning, K. (1993). Measurement of fugacity of $\mathrm{CO}_{2}$ in seawater using continuous and discrete sampling methods. Mar. Chem., 44: 189-204.

Whitfield, M. and Jagner, D. (1981). Seawater as an electrochemical medium. In: M. Whitfield and D. Jagner (eds.), Marine Electrochemistry. John Wiley, New York, pp. 3-66. 